\title{
ANTESEDEN DAN IMPAK KOMITMEN ORGANISASIONAL PADA ORGANISASI PUBLIK
}

\author{
Muhammad Lizamul Widad Firhana \\ Fakultas Ekonomika dan Bisnis, Universitas Gadjah Mada \\ Budi Santoso \\ Fakultas Ekonomika dan Bisnis, Universitas Gadjah Mada \\ e-mail: budi_santoso@fe.ugm.ac.id
}

\begin{abstract}
This study aims to examine Balfour and Wechsler' organizational commitment construct for public organizations and to strengthen the legitimacy of the organizational commitment construct, especially in the differed nation culture. The organizational commitment for public organizations consists of identification commitment, affiliation commitment, and exchange commitment. The antecedent variables of organizational commitment are participation, politic penetration, supervisor quality, career development, public service, learning, and the satisfied salary. This study has 215 respondents from the regional government institutions in East Java, Indonesia. With path analysis method, this study produces results that opportunity to participation and clarity in career positively influence all of the organizational commitments. Meanwhile, other antecedent variables partially affect each organizational commitment. Furthermore, the impact of the organizational commitment has different strength. Commitment of identification and exchange provide the impact on increasing the willingness to stay. The impact of affiliation commitment is only for the willingness to perform citizenship behavior.
\end{abstract}

Keywords: Antecendent, organizational commitment, public organizations.

\begin{abstract}
Abstrak
Penelitian ini bertujuan menguji konstruk komitmen organisasional di sektor organisasi publik. Pengujian ini juga bertujuan memperkuat legitimasi konstruk komitmen organisasional untuk organisasi publik, khususnya di lingkungan budaya yang berbeda. Komitmen organisasional terdiri dari identifikasi, afiliasi, dan pertukaran. Anteseden komitmen organisasional terdiri dari partisipasi, penetrasi politik, kualitas supervise, peningkatan karier, pelayanan publik, pembelajaran, dan kepuasan gaji. Sedangkan keluaran komitmen di sektor publik terdiri dari keinginan bertahan, intensi turnover, dan perilaku ekstra. Partisipasipan berjumlah 215 pegawai di lingkungan Pemerintah Daerah. Dengan menggunakan analisis jalur, penelitian menghasilkan kesimpulan bahwa hanya kesempatan berpartipasi dan kejelasan karier mempengaruh secara positif ketiga jenis komitmen organisasional sektor publik, sedangkan variabel anteseden lain bersifat terbatas hanya mempengaruhi salah satu komitmen organisasional sektor publik. Sedangkan impak setiap komitmen berbeda-beda. Komitmen identifikasi dan pertukaran memberikan impak pada keinginan bertahan dan mengurangi intense turnover. Impak komitmen afiliasi yaitu hanya pada keinginan berperilaku ekstra melampui konteks bidang pekerjaannya.
\end{abstract}

Kata kunci: Antesenden, komitmen organisasional, organisasi publik.

\section{PENDAHULUAN}

Pengembangan konstruk komitmen organisasional di lingkungan organisasi sektor publik sangat diperlukan karena beberapa hal. Pertama, keterbatasan studi empiris telah mengakibatkan konstruksi komitmen organisasional di sektor publik belum memiliki legitimasi yang cukup untuk diaplikasikan di organisasi sektor publik (Balfour and Wechsler, 1996). Kedua, terdapat perbedaan anteseden 
komitmen organisasional baik di organisasi sektor privat dan sektor publik (Balfour and Wechsler, 1996). Komitmen organisasional karyawan di sektor privat dipengaruhi oleh karakteristik pekerjaan, pengalaman bekerja di organisasi, dan karakteristik personal (Steers, 1977), sedangkan komitmen organisasional karyawan di sektor publik banyak didominasi oleh pengaruh pengalaman bekerja di organisasi (Balfour and Wechsler, 1996).

Ketiga, terdapat perbedaan dominasi komitmen organisasional baik di organisasi sektor publik dan sektor privat (Padma and Nair, 2009). Studi mengungkapkan bahwa komitmen pada tujuan dan nilai organisasional mendominasi temuan komitmen organisasional di organisasi sektor publik, namun komitmen untuk tetap menjadi anggota organisasi tersebut sangatlah rendah (Balfour and Wechsler, 1996). Hal sebaliknya terjadi di organisasi sektor privat. Hal ini mengindikasikan bahwa konstruk komitmen organisasional di organisasi sector privat belum bisa menjelaskan komitmen organisasional di sektor publik. Ketiga alasan di atas cukup memberikan panduan bagi peneliti untuk mengonstruksi komitmen organisasional di organisasi publik secara spesifik. Konstruksi komitmen organisasional di organisasi publik hanya diteliti oleh sebagian kecil peneliti (Angel and Perry, 1981; O'Reilly and Chatman, 1986; serta Balfour and Wechsler, 1996) dibandingkan dengan peneliti komitmen organisasional di organisasi privat (Becker, 1960; Steers, 1977; Allen and Meyer, 1990; Jaros et al., 1993; Meyer and Herscovitch, 2001). Oleh karenanya, pengembangan pengembangan konstruk teori dan pencarian bukti empiris di organisasi sektor publik merupakan topik penelitian yang sangat menarik untuk dieksplorasi. Melihat krusialnya peran komitmen organisasional di organisasi sektor publik, upaya awal yang harus dilakukan adalah mengetahui dan menguji apa saja anteseden dan outcome yang dihasilkan oleh komitmen organisasional serta bagaimana pengaruh yang dihasilkannya.

Dalam rangka itu, penelitian ini mereplikasi hasil penelitian yang dilakukan Balfour and Wechsler (1996). Pemilihan replikasi tersebut memiliki dua alasan. Pertama, meskipun riset dan teori komitmen organisaional cukup berkembang pesat, ada keterbatasan pengembangan dan pengujian konstruk tersebut di penelitian di organisasi publik (Balfour and Wechsler, 1996; Romzek, 1985; Flynn and Tannenbaum, 1993; Liou, 1995; dan Ahmad et al., 2010). Kedua, konstruk komitmen organisasional di organisasi publik yang dikembangkan oleh Balfour and Wechsler dalam konteks budaya yang berbeda dengan lingkungan Indonesia. Penelitian tertarik menguji sejauh mana semua variabel-variabel anteseden mampu mempengaruhi komitmen organisasional dan komitmen organisasional mempengaruhi variabel-variabel keluaran (outcome).

\section{KAJIAN PUSTAKA Organsiasi Sektor Publik}

Secara umum pemberdaan antara organisasi sektor publik dan privat terletak pada orientasi keuntungan, meskipun kedua sektor tersebut berfungsi memberikan pelayanan publik, organisasi publik tidak beorientasi keuntungan. Lebih jauh, Perry and Rainey (1988) membedakan organisasi publik dan privat berdasarkan tiga karakteristik yaitu kepemilikan, pengaruhnya pada masyarakat secara langsung, dan keterbukaan pada pengaruh dari luar. Hal ini tidak terlepas dari faktor kepemilikan dan sumber pendanaan (melalui pajak) yang dilakukan oleh organisasi publik. Secara umum, organisasi sektor publik lebih dikaitkan dengan organisasi pemerintah, sedangkan dan organisasi privat diasosiasikan dengan perusahaan.

\section{Komitmen Organisasional}

Tabel 1 menjelaskan beberapa definisi komitmen organisasional. Perbedaan dimensionalitas komitmen organisasional dikarenakan perbedaan motif dan strategi pengembangannya (Meyer and Herscovitch, 2001).

\section{Komitmen Organisasional di Organisasi Sektor Publik}

Balfour and Wechsler (1996) merumuskan bahwa komitmen organisasional di organisasi publik terdiri dari identifikasi, afiliasi, dan pertukaran. Komitmen identifikasi merupakan komitmen organisasional terkait dengan proses karyawan mengidentifikasikan diri dengan misi dan tujuan organsasi. Dimensi komitmen ini berupa perasaan senang bergabung pada organisasi, meskipun perasaan ini berawal dari 
pandangan publik bahwa bergabung dengan organisasi publik adalah sebuah kehormatan. Lebih jauh, Balfour and Wechsler (1996) memperluas definisi komitmen identifikasi dengan memasukkan faktor perasaan karyawan pada misi, tujuan, dan pencapaian organisasi.

Komitmen afiliasi merupakan presepsi karyawan tentang perhatian dan kepemilikan. Afiliasi diderivasikan dari perasaan karyawan bahwa anggota lain dari organisasi tersebut memiliki perhatian (care) terhadap individu. Selain itu, komitmen afiliasi muncul karena rasa kepemilikan dan kebersamaan yang dimiliki bersama-sama. Rasa kepemilikan bertransformasi pada rasa kepemilikan pada organisasi. Dengan kata lain, komitmen afiliasi dipengaruhi keterkaitan psikologis karyawan pada relasi sosial yang telah terbentuk di dalam organisasi (Balfour and Wechsler, 1990). Komitmen pertukaran mengacu pada keterikatan psikologis karyawan akibat hubungan resiprokal (simbiosis mutualisme) antara individu dan organsiasi. Hubungan resiprokal ini berkaitan dengan keberadaan kompensasi moneter maupun non-moneter. Meskipun keberadaan kompensasi moneter pada penelitian sebelumnya (O'Reilly and Chatman, 1986; Padma and Nair, 2009) memiliki hubungan yang lemah pada komitmen organisasional, hasil penelitian Balfour and Wechsler (1996) justru menganggap penting adanya jenis komitmen ini. Keterikatan psikologis yang berbasis pertukaran akan menguat bersamaan dengan pengakuan kontribusi karyawan kepada organisasi, ketersediaan dukungan, dan dorongan positif organisasional.

Tabel 1: Bentuk-Bentuk Komitmen Organisasional

\begin{tabular}{|c|c|}
\hline \multicolumn{2}{|l|}{ Angel and Perry (1981) } \\
\hline Komitmen nilai & "komitmen untuk menyokong tujuan organisasi" \\
\hline Komitmen untuk tinggal & "komitmen untuk tetap menjadi anggota organisasi" \\
\hline \multicolumn{2}{|c|}{ O'Reilly and Chatman (1986) } \\
\hline Complience & "komitmen instrumental untuk kompensasi ekstrinsik yang spesifik" \\
\hline Identifikasi & $\begin{array}{l}\text { "keterikatan yang didasarkan pada keinginan untuk menjadi anggota } \\
\text { organisasi" }\end{array}$ \\
\hline Internalisasi & $\begin{array}{l}\text { "keterlibatan yang mendasari keselarasan antara individu dan nilai } \\
\text { organisasi" }\end{array}$ \\
\hline \multicolumn{2}{|l|}{ Meyer and Allen (1991) } \\
\hline Afektif & $\begin{array}{l}\text { "keterikatan emosional karyawan pada organisasi, tingkat pengidentifkasian } \\
\text { diri dengan organsiasi, dan keikutsertaan pada organisasi"" }\end{array}$ \\
\hline Normatif & "sebuah perasaan yang mewajibkan untuk tetap bekerja pada organisasi" \\
\hline Continuance & $\begin{array}{l}\text { "perhatian khusus pada beban yang berasosiasi dengan keputusan untuk } \\
\text { meninggalkan organisasi" }\end{array}$ \\
\hline \multicolumn{2}{|l|}{ Jaros et al. (1993) } \\
\hline Afektif & $\begin{array}{l}\text { "tingkat keterkaitan psikologis untuk loyal, menyukai, dan memiliki } \\
\text { organisasi" }\end{array}$ \\
\hline Continuance & $\begin{array}{l}\text { "perasaan terkurung pada suatu organisasi yang dikarenakan tingginya kos } \\
\text { untuk keluar dari organisasi" }\end{array}$ \\
\hline Moral & "tingkat keterkaitan psikologis pada tujuan, nilai, dan misi organisasi" \\
\hline \multicolumn{2}{|c|}{ Balfour and Wechsler (1996) } \\
\hline Afiliasi & $\begin{array}{l}\text { "keterikatan psikologis yang diakibatkan oleh relasi sosial yang } \\
\text { berkembang dalam organisasi" }\end{array}$ \\
\hline Identifikasi & $\begin{array}{l}\text { "keterikatan psikologis yang diakibatkan oleh pengidentifikasian diri } \\
\text { individu pada misi dan tujuan organisasi" }\end{array}$ \\
\hline pertukaran & $\begin{array}{l}\text { "keterikatan psikologis yang diakibatkan oleh hubungan resiprokal individu } \\
\text { dan organisasi" }\end{array}$ \\
\hline
\end{tabular}

Sumber: Diolah dari Meyer and Herscovitch (2001) 


\section{Anteseden Komitmen Organisasional}

Anteseden komitmen organisasional dipengaruhi oleh faktor organisasional dan individual. Mayer and Schoorman (1998) menguatkan hal tersebut bahwa proses pertukaran antara individu dan organisasi yang sehat menjadi pertimbangan individu (karyawan) berpartisipasi aktif proses organisasional. Selain itu, perlakuan organisasi terhadap karyawan dapat menguatkan komitmen karyawan untuk loyal kepada organisasinya. Penelitian empiris menyatakan bahwa ada tiga faktor berperan sebagai anteseden komitmen organsiasional yaitu karakteristik personal, karakteristik pekerjaan, dan pengalaman kerja (Steers, 1977). Faktor karakteristik personal terdiri dari faktor usia, kebutuhan akan pencapaian tertentu, dan tingkat pendidikan yang melekat pada individu (karyawan). Selanjutnya, faktor karakteristik pekerjaan terdiri dari subfaktor keberadaan mekanisme feedback identitas tugas, dan kesempatan berinteraksi sosial di organsiasi. Terakhir, faktor pengalaman kerja terdiri dari tiga subfaktor yaitu: sikap pada organisasi, tingkat ketergantungan dan kepercayaan pada organisasi, serta kompensasi yang didapatkan.

Studi-studi empiris juga menambah faktor-faktor anteseden komitmen organisasional. Sebagai contoh, Chusmir (1988) memasukkan faktor gender pada analisisnya, Flynn and Tannebaum (1993) menambahkan analisis mengenai karakter organisasi, dan Padma and Nair (2009) menelaah kultur organisasi sebagai bagian anteseden komitmen organisasional. Hasil penelitian anteseden komitmen organisasional di organisasi sektor privat berbeda dengan temuan di organisasi sektor publik. Sebagai contoh, Balfour and Wechsler (1996) menyatakan bahwa faktor karakteristik personal bukan anteseden komitmen organisasional di organisasi publik. Selanjutnya, studi empiris menjelaskan bahwa karakteristik personal (usia, tingkat pendidikan, motivasi internal) justru berpengaruh langsung pada outcome komitmen organisasional. Lebih jauh, komitmen karyawan pada organsasi publik didominasi oleh pengaruh pengalaman kerja dan karakteristik pekerjaan itu sendiri.

\section{Keluaran Komitmen Organisasional}

Steers (1977) mengungkapkan setidaknya beberapa jenis outcome komitmen organi- sasional yaitu keinginan (desire) untuk tetap di organisasi, intensi (intent) tetap di organisasi, kedatangan, dan kinerja kerja. Di sisi lain, banyak peneliti yang mencoba mencari hubungan komitmen organisasional dengan jenis perilaku kerja lainnya yaitu antara lain dengan Organizational Citizenship Behaviour (OCB) (Ahmad et al., 2010), perilaku inovatif karyawan (Jafri, 2010), perilaku ekstra dari peran yang seharusnya dilakukan (Balfour and Wechsler, 1996).

Secara umum, peneliti menghubungkan komitmen organisasional dengan keinginan karyawan untuk tetap menjadi anggota organisasi (Steers, 1977; Jaros et al., 1993; Balfour and Wechsler, 1996; Ahmad et al., 2010). Karyawan berkomitmen tinggi pada organisasi memiliki rasa kepemilikan pada organisasi yang besar dan mau untuk mengeluarkan usaha lebih demi tercapainya tujuan organisasi serta rela mendahulukan kepentingan organisasi daripada kepentingan individu (Balfour and Wechsler, 1996). Di organisasi sektor publik, outcome komitmen organisasional berupa keinginan untuk tetap menjadi anggota organisasi tentu tidak bisa hilang begitu saja. Penelitian Balfour and Wechsler (1996) menemukan beberapa outcome yang muncul dari komitmen organisasonal . Pertama, keinginan karyawan untuk tetap menjadi anggota organisasi. Keinginan ini menguat bersamaan dengan peningkatan kualitas hubungan sosial antar individu dan mekanisme pertukaran antara individu dan organisasi. Selain itu, jenis outcome ini juga dipengaruhi oleh tingkat pendidikan karyawan serta presepsi mengenai alternatif pekerjaan lain. Kedua, lama bekerja seorang karyawan di organisasi juga mempengaruhi tingkat keinginan seseorang untuk meninggalkan organisasi. Lama bekerja secara tidak langsung membentuk pola rutinitas yang dianggap nyaman bagi karyawan, sehingga mengurangi keinginan untuk berpindah (turnover) (Becker, 1960).

Terakhir, perilaku ekstra yang melebihi peran yang seharusnya dilakukan. Balfour and Wechsler (1996) menemukan bahwa jenis outcome ini hanya dipengaruhi komitmen organisasional yang didasari pada proses relasi sosial dalam organisasi. Selain itu, perilaku ekstra ini juga dipengaruhi oleh motivasi internal, posisi/jabatan, serta tingkat pelayanan langsung pada masyarakat yang dialami oleh 
pekerja. Hal ini terjadi karena karakteristik organisasi publik yang menonjolkan tingkat birokrasi yang tinggi serta perlunya kerjasama antar elemen dalam melayani kepentingan publik.

\section{Pengembangan Hipotesis}

Penelitian ini mengelompokkan variabel-variabel komitmen organisasional ke dalam tiga kelompok yaitu anteseden komitmen organisasional, bentuk komitmen organisasional, dan outcome komitmen organisasional (lihat tabel 2). Selanjutnya, pengembangan hipotesis atas variabel-variabel komitmen organisasional berdasarkan hubungan teoritis dan studi empiris relevan.

\section{Anteseden Komitmen Identifikasi}

\section{Partisipasi}

Balfour and Wechsler (1996) menyatakan bahwa seluruh karyawan pasti ingin diikutsertakan dalam proses pengambilan keputusan yang berimplikasi pada pekerjaannya dan perannya di organisasi. Proses identifikasi seseorang terhadap organasiasi akan menguat ketika pihak manajemen mendengarkan aspirasi dan mendukung karyawannya. Dan sebaliknya, proses identifikasi akan melemah jika pihak manajemen bertindak otoriter pada karyawannya.

H1: Partisipasi dalam pengambilan keputusan berpengaruh positif terhadap komitmen identifikasi.

\section{Pelayanan Publik}

Komitmen identifikasi salah satunya disebabkan oleh legitimasi publik akan kontribusinya pada pelayanan publik. Ketika seorang karyawan mempunyai kesempatan lebih besar untuk melayani publik secara langsung, ia memiliki peluang untuk mendapatkan legitimasi lebih banyak dari publik (Balfour and Wechsler, 1996).

$\mathrm{H} 2$ : peluang untuk melayani publik secara langsung berpengaruh positif terhadap komitmen identifikasi.

\section{Cakupan Pekerjaan}

Hackman and Oldham (1976) menyatakan bahwa semakin luas cakupan pekerjaan seseorang meningkatkan persepsi atas kesempatannya berkontribusi pada pencapaian organisasi.

H3: Luasan Cakupan Pekerjaan karyawan berpengaruh positif terhadap komitmen identifikasi.

\section{Penetrasi Politis}

Studi empiris oleh Balfour and Wechsler (1996) mengungkapkan bahwa dominasi pengaruh politik pada pengambilan keputusan dan praktik manajerial rentan menimbulkan perasaan tidak adil pada karyawan sehingga melemahkan komitmen identifikasi pada karyawan publik.

H4: Penetrasi pengaruh politik pada praktik manajerial berpengaruh negatif terhadap komitmen identifikasi.

\section{Kualitas Supervisi}

Proses supervisi merupakan representasi kepedulian organisasional yang ditunjukkan kepada karyawan untuk pencapaian tujuan individu dan organisasi (Carnevale and Wechsler, 1992). Maka kualitas supervisi yang baik dapat meningkatkan komitmen karyawan untuk mengidentifikasikan diri pada organisasi (Balfour and Wechsler, 1996).

H5: Kualitas supervisi berpengaruh positif terhadap komitmen identifikasi.

Tabel 2: Pembagian Kelompok Variabel

\begin{tabular}{llll}
\multicolumn{1}{c}{ Anteseden } & Komitmen Organisasional & \multicolumn{1}{c}{ Outcome } & \multicolumn{1}{c}{ Lain-lain } \\
\hline Partisipasi & Identifikasi & Keinginan untuk & Motivasi Internal \\
Penetrasi Politik & Afiliasi & Bertahan & Posisi \\
Kualitas supervisi & Pertukaran & Intensi turnover & Tingkat Pendidikan \\
Peningkatan karier & & Perilaku Ekstra & Alternatif Pekerjaan \\
Pelayanan publik & & & Tenure \\
Pembelajaran & & & \\
Kepuasan Gaji & & & \\
\hline
\end{tabular}

Diolah dari Balfour and Wechsler (1996) 


\section{Pengembangan Karier}

Studi empiris Balfour and Wechlser (1996) mengungkapkan bahwa adanya kesempatan pengembangan karier dalam organisasi mengindikasikan kepedulian organsiasi mempertahankan karyawannya. Semakin besar kesempatan pengembangan karier mempengaruhi presepsi karyawan bahwa dirinya mampu berkontribusi dalam pencapaian tujuan organisasi.

H6: semakin banyak kesempatan untuk mengembangkan karier di organisasi berpengaruh positif terhadap komitmen identifikasi.

\section{Anteseden Komitmen Afiliasi}

\section{Partisipasi}

Kesempatan karyawan berpatisipasi pada proses pengambilan keputusan tentang pekerjaannya merupakan indikasi bahwa organisasi menghargai keberadaan seorang karyawan di organisasi. Hal ini merupakan salah basis penting penumbuhan keterikatan emosional dalam organsiasi pada sebuah kelompok kerja di organsisasi (O'Reilly and Chatman, 1986). Berkaitan dengan hal tersebut, semakin tinggi tingkat kesempatan untuk berpartisipasi meningkatkan presepsi tentang eksistensi seorang karyawan di organisasi.

H7: semakin tinggi tingkat partisipasi karyawan pada proses pengambilan keputusan berpengaruh positif terhadap komitmen afiliasi.

\section{Penetrasi Politik dan Kualitas Supervisi}

Studi empiris oleh Balfour and Wechsler (1996) mengungkapkan bahwa penetrasi politik dan kualitas supervisi menentukan iklim organisasi dan hubungan antar anggota organisasi. Penetrasi politik dapat menurunkan komitmen afiliasi karena rasa ketidakadilan pada karyawan. Kualitas supervisi menciptakan lingkungan yang saling mendukung dan mempercayai di dalam organisasi ( Carnavale and Wechsler, 1992).

H8: Penetrasi politis pada praktik manajerial berpengaruh negatif terhadap komitmen afiliasi.

H9: Kualitas supervisi yang dilakukan pada karyawan berpengaruh positif terhadap komitmen afiliasi.

\section{Pengembangan Karier}

Studi empiris Balfour and Wechsler (1996) menyatakan bahwa kejelasan pengembangan karier memiliki pengaruh positif terhadap komitmen karyawan yang berdasar pada relasi sosial di organanisasi dan kepastian bagi karyawan akan kelangsungan kerjanya di organisasi di masa datang.

H10: kesempatan mengembangkan karier berpengaruh positif terhadap komitmen afiliasi

\section{Anteseden Komitmen Pertukaran}

\section{Partisipasi dan Penetasi Politik}

Kesempatan berpartisipasi berperan penting pada penguatan hubungan timbal balik antara karyawan dan organisasi dan selanjutnya memiliki pengaruh paling kuat pada keberadaan komitmen organisasional karyawan Balfour and Wechsler (1996).

H11: Partisipasi pada proses pengambilan keputusan berpengaruh positif terhadap komitmen pertukaran.

Kemudian, pengaruh politik pada proses pengambilan keputusan akan merusak hubungan resiprokal antara individu dan organisasi karena menciptakan persepsi ketidakadilan di kalangan karyawan. Secara spesifik, Mosher (dalam Balfour and Wechsler, 1996) mengungkapkan bahwa praktik pengaruh politik pada proses organisasional telah mengabaikan kontrak kerja yang telah disepakati oleh karyawan dan organisasi.

H12: Penetrasi politik pada proses pengambilan keputusan dan praktik manajerial berpengaruh negatif terhadap komitmen pertukaran.

\section{Kualitas Supervisi}

Seperti di atas, kualitas supervisi yang baik merupakan dukungan dan memfasilitasi pencapaian kinerja optimal karyawan dan pada akhirnya kerja bagi karyawan menguatkan komitmen pertukaran yang dirasakan karyawan (Balfour and Wechsler, 1996).

H13: Kualitas supervisi yang dilakukan oleh organisasi meningkatkan komitmen pertukaran. 


\section{Pengembangan Karier dan Pembelajaran}

Penawaran pengembangan karier bagi karyawan merupakan representasi evaluasi perkembangan perannya atas tujuan organisasi (Balfour and Wechsler, 1996). Ketika kesempatan-kesempatan untuk mengembangkan karier disediakan memadai, komitmen pertukaran antara karyawan dan organisasi akan meningkat.

H14: kesempatan pengembangan karier berpengaruh positif terhadap komitmen pertukaran.

Studi empiris yang dilakukan oleh Balfour and Wechsler (1996) mengungkapkan bahwa kesempatan untuk mendapatkan pembelajaran dalam proses kerja pada karyawan publik akan meningkatkan komitmen organisasionalnya. Hal tersebut menunjukkan proses resiprokal antara karyawan dan organisasi tidak hanya dalam bentuk material.

H15: kesempatan mendapatkan pembelajaran berpengaruh komitmen pertukaran.

\section{Kepuasan Gaji}

Gaji adalah salah satu penyebab penting yang mendasari komitmen pertukaran (Balfour and Wechsler, 1996). Hal ini dikarenakan karyawan hanya akan mau memberikan usaha dan pengorbanan yang lebih besar pada organisasi jika diberi kompensasi yang seimbang, adil, dan lebih baik.

H16: kepuasan gaji yang didapatkan berpengaruh positif terhadap komitmen pertukaran.

\section{Anteseden Keinginan untuk Bertahan (Desire to Remain)}

Komitmen Afiliasi, Identifikasi, dan Pertukaran

Secara umum telah disimpulkan bahwa keinginan karyawan untuk bertahan di organisasi adalah outcome dari tiga bentuk (dimensi) komitmen organisasional. Karyawan berkeinginan bertahan di organisasi adalah karena memiliki tingkat identifikasi (internalisasi) tinggi terhadap misi, tujuan dan pencapaian organisasi dan memiliki kepuasan pada proses hubungan resiprokal dengan organisasi serta memiliki keterikatan sosial yang kuat pada anggota lain di organisasi.
H17: komitmen identifikasi berpengaruh positif terhadap keingian karyawan untuk bertahan di organisasi.

H18: Komitmen afiliasi berpengaruh positif terhadap keingian karyawan untuk bertahan di organisasi.

H19: Komitmen pertukaran berpengaruh positif terhadap keingian karyawan untuk bertahan di organisasi.

\section{Tingkat Pendidikan}

Studi empiris oleh Balfour and Wechsler (1996) terungkap bahwa tingkat pendidikan berpengaruh negatif dengan keinginannya bertahan di satu organisasi. Tingkat pendidikan seseorang mencerminkan semakin tinggi keahliannya. Hal ini tentu memperbesar peluang seseorang mendapatkan kesempatan mendapat banyak pekerjaan. Hal ini dapat mempengaruhi komitmen seseorang untuk tetap bertahan di satu organasasi.

H20: Tingkat pendidikan yang dimiliki seseorang berpengaruh negatif terhadap keinginannya untuk bertahan di organisasi

\section{Alternatif Pekerjaan}

Meningkatnya ketersediaan alternatif pekerjaan lain bagi seseorang dapat mengurangi keinginan seseorang untuk bertahan di organisasi. Studi empiris oleh Balfour and Wechsler (1996) menyatakan bahwa persepsi mengenai ketersediaan alternatif pekerjaan bagi karyawan dapat berpengaruh negatif terhadap keinginan karyawan untuk tetap berada di satu organisasi.

H21: presepsi dapat keberadaan alternatif pekerjaan yang lebih baik berpengaruh negative terhadap keinginan bertahan di organisasi.

\section{Anteseden Intensi Turnover}

\section{Keinginan untuk Bertahan}

Intensi untuk turnover merefleksikan keinginan individu untuk mencari alternatif pekerjaan dan meninggalkan organisasi. Dengan demikian keinginan seseorang untuk bertahan di organisai mengurangi intensinya untuk mencari alternatif pekerjaan di luar organisasi

H22: Keinginan untuk bertahan di organisasi berpengaruh negatif terhadap intensi karyawan untuk turnover. 


\section{Tenure}

Studi yang dilakukan oleh Balfour and Wechsler (1996) menemukan bahwa lama masa kerja seorang karyawan publik akan menurunkan intensinya untuk melakukan turnover karena seseorang telah banyak melakukan usaha dan pengorbanan demi kepentingan organisasi. Selain itu, lama seseorang bekerja juga mempengaruhi tingkat keterikatan psikologisnya.

H23: lama waktu bekerja di organsiasi berpengaruh negatif terhadap intensi karyawan untuk turnover.

\section{Anteseden Perilaku Ekstra-Peran (Extrarole Behaviour)}

\section{Komitmen Afiliasi}

Seseorang yang memiliki keterkaitan sosial yang kuat terhadap anggota lain di organisasi lebih memungkinkan untuk melakukan usaha lebih banyak untuk membantu relasinya maupun organisasinya (O'Reilly and Chatman, 1996). Studi yang dilakukan oleh Balfour dan Wechsler (1996) mendukung pernyataan di atas. Selanjutnya, tingginya komitmen afiliasi dapat membentuk lingkungan kerja yang kondusif dan saling mendukung.
H24: Komitmen afiliasi berpengaruh positif kemauan seseorang untuk berperilaku melebihi peran yang ia dapatkan.

\section{Motivasi Internal}

Individu dengan motivasi internal tinggi memungkinkan untuk berperan lebih daripada tugas yang telah dibebankan. Studi empiris Balfour and Wechsler (1996) juga mendukung adanya pengaruh yang ditimbulkan oleh motivasi internal karyawan terhadap keinginannya untuk berperan melebihi kewajiban yang dibebankan.

H25: Motivasi internal yang dimiliki karyawan berpengaruh positif terhadap keinginannya utnuk berperan lebih di organsiasi.

\section{Posisi/Jabatan di Organisasi}

Studi yang dilakukan oleh Balfour and Wechsler (1996) menemukan bahwa posisi/jabatan yang dimiliki oleh seorang karyawan berjalan selaras dengan keinginannya untuk memiliki peran lebih banyak di organsisasi. Semakin tinggi posisi seseorang maka ia punya peran yang lebih besar di organisasi.

H26: semakin tinggi posisi seseorang berpengaruh positif terhadap kemauannya untuk berperan lebih di organisasi.

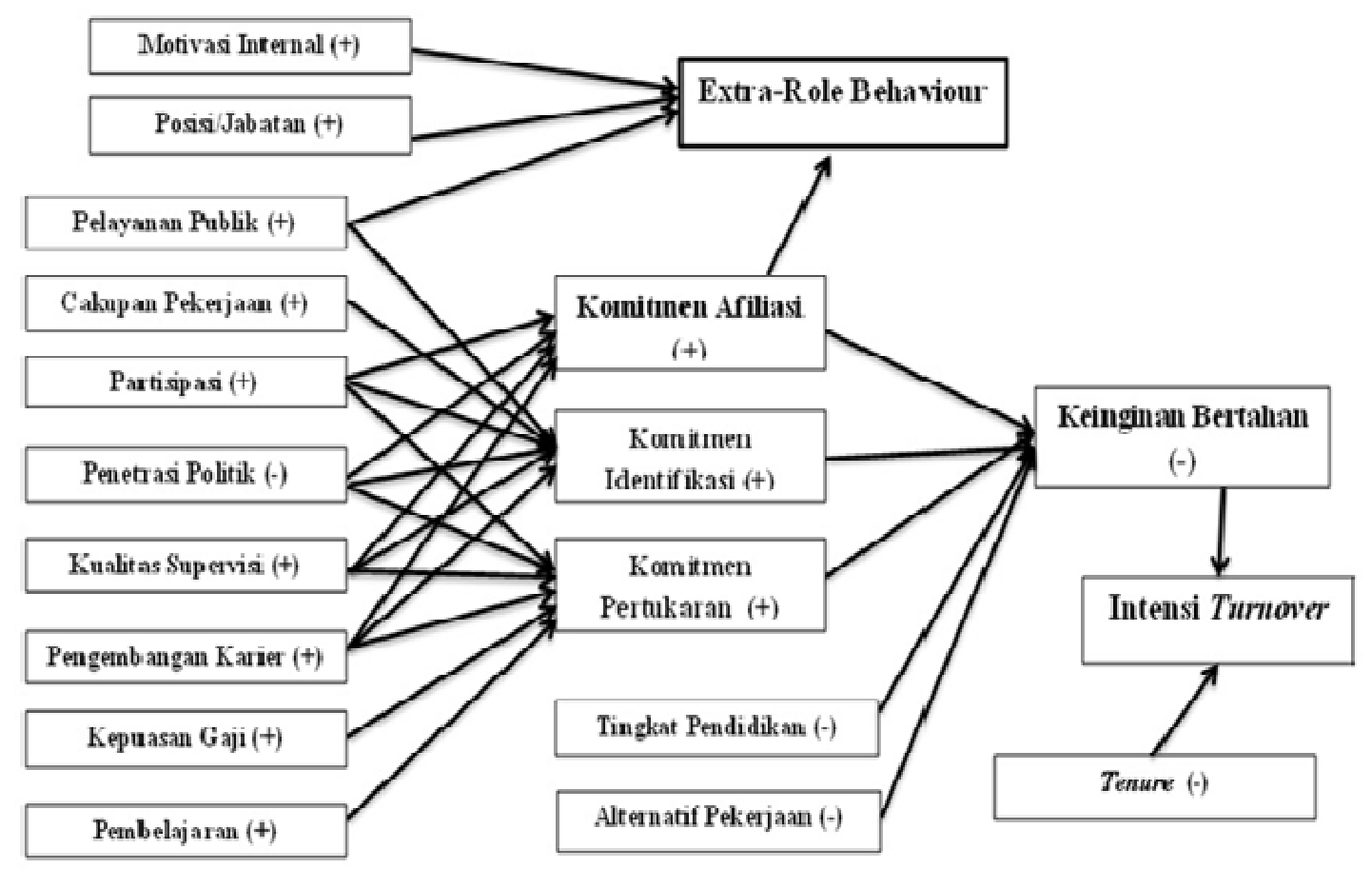

Gambar 1: Bagan Perumusan Hipotesis 


\section{Pelayanan Publik}

Kesempatan seorang melakukan pelayanan publik langsung akan mempengaruhi motivasinya untuk berbuat lebih pada organisasi. Hasil studi Balfour and Wechsler (1996) menambahkan bahwa kesempatan untuk memberika pelayanan pada publik secara langsung merupakan sebuah kehormatan dari publik bagi dirinya.

H27: semakin tinggi kesempatan untuk melayani publik secara langsung meningkatkan kemauannya untuk berperan lebih pada organisasi.

\section{METODA PENELITIAN Populasi dan Sampel Penelitian}

Populasi penelitian ini adalah pegawai negeri di Pemerintahan Daerah Kabupaten Lumajang. Karakteristik sampel yang akan diambil pada penelitian ini adalah Pegawai Negeri Sipil (PNS) di lingkungan PEMDA Kabupaten Lumajang minimal selama satu tahun. Tujuan pengambilan karakteristik sampel tersebut untuk menghindari bias dalam pengukuran komitmen organisasional. Pengalaman bekerja tersebut dianggap telah membentuk komitmen organisasional pada diri karyawan PNS. Penelitian ini menggunakan metode pengambilan sampel acak terstrata (stratified random sampling). Stratifikasi pada penelitian ini berbasis pada strata golongan pegawai yang ada di lingkup Pemerintah Daerah Kabupaten Lumajang, kemudian baru dilakukan pengambilan secara acak di setiap strata yang ada.

\section{Pengukuran Variabel}

Pengukuran data pada penelitian ini mengacu pada kuesioner yang dikembangkan oleh Balfour and Wechsler (1996) dengan beberapa alasan sebagai berikut. Pertama, kuesioner tersebut didesain untuk penelitian mengenai anteseden dan outcome komitemen organisasional di organisasi publik. Kedua, konstruk yang dikembangkan memiliki tingkat reliabilitas yang tinggi yaitu 0.83 untuk komitmen pertukaran, 0.81 untuk komitmen afiliasi dan
0.72 untuk komitmen identifikasi. Skala pengukuran dalam penelitian ini mengunakan 7 poin skala likert $(7=$ sangat setuju, $1=$ Sangat tidak setuju). Semakin tinggi jawaban yang diberikan oleh objek penelitian, maka semakin tinggi pula nilai konstruk teori tertentu. Kemudian, pada item tertentu yang didesain sebagai pertanyaan terbalik, maka pada item tersebut dilakukan pembalikan nilai untuk menjaga konsistensi konstruknya. Metode analisis data yang digunakan pada penelitian ini adalah analisis jalur.

\section{HASIL ANALISIS Penyebaran Kuesioner}

Tabel 3 menjelaskan jumlah penyebaran kuesioner yaitu sebanyak 300 kuesioner dan jumlah kuesioner dianalisis yaitu sebanyak 215 kuesionerr. Kuesioner layak dianalisis adalah kuesioner yang diisi penuh atau dijawab keseluruhan.

\section{Statistik Deskriptif}

Tabel 4 menampilkan hasil statistik deskriptif. Nilai komitmen afiliasi memiliki nilai rata-rata tertinggi yaitu 4.81. Tingginya nilai komitmen afiliasi menggambarkan pengaruh keterikatan psikologis karena adanya relasi-relasi sosial dibandingkan proses identifikasi diri pada organisasi dan hubungan timbal-balik antara organisasi dan indidvidu. Beberapa variabel anteseden atau penyebab komitmen organisasi yang memiliki nilai rata-rata cukup tinggi yaitu kualitas supervisi, cakupan pekerjaan, kepuasan gaji, dan pembelajaran. Hasil olah statistik tersebut mengindikasikan beberapa temuan. Pertama, kegiatan supervisi yang dilakukan oleh atasan memiliki kualitas yang cukup baik sehingga menciptakan iklim saling mendukung dan saling mempercayai dalam organisasi. Kedua, pekerjaan yang dilaksanakan mempunyai cakupan kerja yang luas dan penting dalam kerangka kerja organsiasi. Terakhir, ada kepuasaan internal sehingga komitmen atas pekerjaan dan proses pembelajaran berjalan baik.

Tabel 3: Hasil distribusi kuesioner

\begin{tabular}{lll}
\hline Keterangan & Frekeuensi & Presentase \\
\hline Total Kuesioner tersebar & 300 & $100 \%$ \\
Total Kuesioner kembali & 219 & $73 \%$ \\
Total Kuesioner tidak kembali & 81 & $27 \%$ \\
Total Kuesioner layak analisis & $\mathbf{2 1 5}$ & $\mathbf{7 2 \%}$ \\
\hline
\end{tabular}


Tabel 4: Statistik deskriptif dan tabel korelasi antar variabel

\begin{tabular}{|c|c|c|c|c|c|c|c|c|c|c|c|c|c|c|c|}
\hline NO & & \multicolumn{2}{|c|}{ Mean } & S.D & 1 & 2 & 3 & \multicolumn{2}{|c|}{4} & \multicolumn{2}{|c|}{5} & \multicolumn{2}{|c|}{6} & 7 & \multirow[t]{2}{*}{8} \\
\hline 1 & KomIdentifika & & 4,5 & 1,5 & 1 & 1 & & & & & & & & & \\
\hline 2 & KomAfiliasi & & 4,8 & 1,6 & $0,78 *$ & 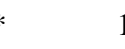 & 1 & & & & & & & & \\
\hline 3 & KomPertukara & & 4,5 & 1,5 & $0,80 *$ & $0,72^{*}$ & & 1 & & & & & & & \\
\hline 4 & Partisipasi & & 4,6 & 1,5 & $0,79 *$ & $0,71^{*}$ & 0,7 & & 1 & & & & & & \\
\hline 5 & PelayananPub & & 4,5 & 1,5 & $0,82 *$ & 0,68 & 0,7 & & $4 *$ & & 1 & & & & \\
\hline 6 & CakupPekerja & & 4,7 & 1,5 & $0,78 *$ & $0,76^{*}$ & 0,7 & & $2 *$ & 0, & $6 *$ & & 1 & & \\
\hline 7 & Pembelajaran & & 4,6 & 1,4 & $0,74 *$ & $0,69^{\prime}$ & 0,6 & & $3 *$ & 0, & & & $77 *$ & 1 & \\
\hline 8 & Politik & & 3,3 & 1,5 & $-0,60 *$ & $-0,59$ & $-0,6$ & -0 & & $-0,6$ & & & $65^{*}$ & $-0,56^{*}$ & 1 \\
\hline 9 & KepGaji & & 4,6 & 1,5 & $0,73 *$ & 0,64 & 0,7 & & $8 *$ & 0, & $5 *$ & & $68 *$ & $0,67 *$ & $-0,65 *$ \\
\hline 10 & PenKarier & & 4,4 & 1,5 & $0,75^{*}$ & $0,67^{*}$ & 0,7 & & $4 *$ & 0, & $4 *$ & & $75^{*}$ & $0,69^{*}$ & $-0,60 *$ \\
\hline 11 & Motivasi & & 4,2 & 1,4 & $0,69 *$ & $0,62^{*}$ & 0,6 & & $5 *$ & 0, & $6^{*}$ & & $64 *$ & $0,65^{*}$ & $-0,49 *$ \\
\hline 12 & Supervisi & & 4,9 & 1,5 & $0,79 *$ & $0,72^{*}$ & 0,7 & & $6 *$ & 0, & $0 *$ & & $77 *$ & $0,70^{*}$ & $-0,60 *$ \\
\hline 13 & Remain & & 4,2 & 1,3 & $0,71^{*}$ & 0,61 & 0,6 & & $5 *$ & 0, & & & $63 *$ & $0,64 *$ & $-0,50 *$ \\
\hline 14 & IntTurnover & & 2,8 & 1,5 & $-0,62 *$ & $-0,62^{\prime}$ & $-0,5$ & -0 & & -0, & & -0 & $60 *$ & $-0,62 *$ & $0,62 *$ \\
\hline 15 & Alternatif & & 3,3 & 1,4 & $-0,36^{*}$ & $-0,31^{\prime}$ & $-0,3$ & -0 & & $-0,3$ & & -0 , & $33 *$ & $-0,36^{*}$ & $0,33 *$ \\
\hline 16 & PerEkstra & & 4,6 & 1,5 & $0,78^{*}$ & 0,74 & 0,7 & & $4 *$ & & $2 *$ & & $73 *$ & $0,71 *$ & $-0,56 *$ \\
\hline 17 & Pendidikan & & 3,4 & 1,1 & $-0,21 *$ & $-0,18$ & $-0,2$ & -0 , & & $-0,2$ & & & $21 *$ & $-0,1$ & $0,18 *$ \\
\hline 18 & Jabatan & & 2,2 & 1,6 & 0,09 & 0,11 & & 0 & $7 *$ & & 01 & &, 13 & $0,16^{*}$ & 0,01 \\
\hline 19 & Tenure & & 9,6 & 8,8 & 0,12 & $0,16^{*}$ & 0,1 & & 11 & & $9 *$ & & $13 *$ & 0,08 & $-0,1$ \\
\hline NO & Variabel & 9 & & 10 & 11 & 12 & 13 & 14 & & 5 & & & 17 & 18 & 19 \\
\hline 9 & KepGaji & & 1 & & & & & & & & & & & & \\
\hline 10 & PenKarier & 0,7 & & 1 & & & & & & & & & & & \\
\hline 11 & Motivasi & 0,6 & & $0,63 *$ & 1 & & & & & & & & & & \\
\hline 12 & Supervisi & 0,7 & & $0,75^{*}$ & $0,71 *$ & 1 & & & & & & & & & \\
\hline 13 & Remain & 0,6 & & $0,62 *$ & $0,70 *$ & $0,68 *$ & 1 & & & & & & & & \\
\hline 14 & IntTurnover & $-0,5$ & & $-0,53^{*}$ & $-0,46^{*}$ & $-0,54^{*}$ & $-0,58 *$ & 1 & & & & & & & \\
\hline 15 & Alternatif & $-0,3$ & & $-0,24 *$ & $-0,28 *$ & $-0,37 *$ & $-0,47 *$ & $0,56^{*}$ & & 1 & & & & & \\
\hline 16 & PerEkstra & 0,7 & & $0,67 *$ & $0,68 *$ & $0,75 *$ & $0,72 *$ & $-0,62 *$ & & $40 *$ & & 1 & & & \\
\hline 17 & Pendidikan & $-0,2$ & & $-0,18^{*}$ & $-0,1$ & $-0,1$ & $-0,23 *$ & $0,19 *$ & & $20 *$ & -0 , & & 1 & & \\
\hline 18 & Jabatan & 0 & 02 & 0,1 & $0,13 *$ & $0,16^{*}$ & 0,07 & $-0,1$ & &, 03 & & $6^{*}$ & $0,29 *$ & 1 & \\
\hline 19 & Tenure & 0,1 & & 0,1 & 0,11 & $0,21 *$ & $0,18 *$ & $-0,1$ & & $15 *$ & & $5 *$ & $-0,25 *$ & $-0,1$ & 1 \\
\hline
\end{tabular}

Ket: * Uji korelasi menunjukkan hasil yang signifikan.

Satu hal menarik dari analisis deskriptif ini adalah ketiga jenis komitmen organisasional terbukti berkorelasi secara signifikan. Signifikannya korelasi antar konstruk komitmen organisasional tersebut mengindikasikan bahwa ada kemungkinan komitmen organisasional merupakan sebuah konstruk yang berdimensi satu (Steers, 1977).

\section{Tes Instrumen Penelitian: Validitas dan Reliabilitas}

Tabel 5 menunjukkan hasil analisis validitas dengan menggunakan metode CFA. Hasil analisis validitas menunjukkan bahwa semua item yang digunakan utuk menjelaskan konstruk pada penelitian ini terbukti valid. Hal tersebut dapat dilihat dari signifikansi nilai loading pada setiap indikator yang ditandai dengan nilai probabilitas $\leq 0.05$. Dengan demikian, dapat disimpulkan bahwa indikator penelitian yang digunakan benar-benar mengukur konstruk yang diinginkan, atau sebaliknya tidak mengukur konstruk yang tidak diinginkan.

Selanjutnya, indeks Goodness-of-Fit model pada pengujian ini menunjukkan bahwa model penelitian ini adalah model yang cukup baik dan sesuai dengan teori. Hal ini bisa dilihat dari beberapa indikator Goodness-of-Fit 
pada Tabel 6. Dari lima (5) indikator goodnessof-fit menunjukkan bahwa model yang diuji secara keseluruhan memiliki nilai fit yang bagus. Meskipun ada satu indikator yang kurang baik (yaitu probabilitas Chi-Square), hal ini dapat dikesampingkan karena indikatorindikator yang lain menunjukkan bahwa nilai fit dari model tersebut adalah baik.

Kemudian, hasil uji keandalan (realibility) instrumen penelitian menunjukkan bahwa instrumen penelitian memiliki realibilitas yang baik. Dari perhitungan composite realibility/construct realibility terungkap bahwa konstruk komitmen organisasional yang diwakili oleh Komitmen Identifikasi, Komitmen Afiliasi, dan Komitmen Pertukaran memiliki nilai sebesar $0.86,0.92$, dan 0.89 . Demikian juga dengan konstruk lainnya, nilai realibilitas konstruk memiliki nilai yang jauh dari nilai minimal sebesar 0.60. Artinya, konstruk-konstruk pada penelitian ini memiliki kemampuan untuk mengukur konstruk secara konsisten lintas waktu.

Tabel 5: Hasil uji validitas instrumen penelitian

\begin{tabular}{|c|c|c|c|c|c|c|c|}
\hline NO & Indikator & Loading & Validitas & No & Indikator & Loading & Validitas \\
\hline 1 & Item 1 & $0,72 * *$ & valid & 22 & Item 22 & $0,87 * *$ & valid \\
\hline 2 & Item 2 & $0,87 * *$ & valid & 23 & Item 23 & $0,91 * *$ & valid \\
\hline 3 & Item 3 & $0,86 * *$ & valid & 24 & Item 24 & $0,92 * *$ & valid \\
\hline 4 & Item 4 & $0,92 * *$ & valid & 25 & Item 25 & $0,80^{* *}$ & valid \\
\hline 5 & Item 5 & $0,91 * *$ & valid & 26 & Item 26 & $0,90^{* *}$ & valid \\
\hline 6 & Item 6 & $0,82 * *$ & valid & 27 & Item 27 & $0,76^{* *}$ & valid \\
\hline 7 & Item 7 & $0,92 * *$ & valid & 28 & Item 28 & $0,81^{* *}$ & valid \\
\hline 8 & Item 8 & $0,84 * *$ & valid & 29 & Item 29 & $0,74 * *$ & valid \\
\hline 9 & Item 9 & $0,79 * *$ & valid & 30 & Item 30 & $0,92 * *$ & valid \\
\hline 10 & Item 10 & $0,92 * *$ & valid & 31 & Item 31 & $0,93 * *$ & valid \\
\hline 11 & Item 11 & $0,87 * *$ & valid & 32 & Item 32 & $0,90^{* *}$ & valid \\
\hline 12 & Item 12 & $0,92 * *$ & valid & 33 & Item 33 & $0,88^{* *}$ & valid \\
\hline 13 & Item 13 & $0,82 * *$ & valid & 34 & Item 34 & $0,75^{* *}$ & valid \\
\hline 14 & Item 14 & $0,91 * *$ & valid & 35 & Item 35 & $0,64^{* *}$ & Valid \\
\hline 15 & Item 15 & $0,91 * *$ & valid & 36 & Item 36 & $0,90 * *$ & Valid \\
\hline 16 & Item 16 & $0,83 * *$ & valid & 37 & Item 37 & $0,94^{* *}$ & Valid \\
\hline 17 & Item 17 & $0,90 * *$ & valid & 38 & Item 38 & $0,96^{* *}$ & Valid \\
\hline 18 & Item 18 & $0,91 * *$ & valid & 39 & Item 39 & $0,71^{* *}$ & Valid \\
\hline 19 & Item 19 & $0,71 * *$ & valid & 40 & Item 40 & $0,79 * *$ & Valid \\
\hline 20 & Item 20 & $0,84 * *$ & valid & 41 & Item 41 & $0,90^{* *}$ & Valid \\
\hline 21 & Item 21 & $0,89 * *$ & valid & 42 & Item 42 & $0,95^{* *}$ & valid \\
\hline
\end{tabular}

Tabel 6: Index Goodness of fit pengukuran CFA

\begin{tabular}{cllrc}
\hline No & \multicolumn{1}{c}{ Indikator Goodness-of-Fit } & \multicolumn{1}{c}{$\begin{array}{c}\text { Cut-off yang } \\
\text { direkomendasi }\end{array}$} & $\begin{array}{c}\text { Hasil } \\
\text { Estimasi }\end{array}$ & Penilaian \\
\hline 1 & Probability Chi-Square & $>0,05$ & 0,00001 & Kurang baik \\
2 & $\begin{array}{l}\text { Root Mean Square Error of Approximation } \\
\text { (RMSEA) }\end{array}$ & $<0,10$ & 0,046 & Sangat baik \\
3 & Expected Cross-Validation Index (ECVI) & model terkecil & 6,63 & Sangat baik \\
4 & Normed Fit Index (NFI) & $>0,90$ & 0,98 & Sangat baik \\
5 & Goodness of Fit Index (GFI) & $>0,90$ & 0,79 & Cukup baik \\
\hline
\end{tabular}




\section{Pengujian Hipotesis}

Tabel 7 di bawah menampilkan hasil analisis jalur secara utuh berdasarkan hipotesis yang dikembangkan pada penelitian ini.

\section{Pengukuran Overall Goodness-of-Fit}

Pengukuran goodness of fit bertujuan mengetahui kelayakan sebuah model penelitian (acceptability of the model). Kelayakan sebuah model memiliki tiga tingkatan indeks fit yaitu absolut, parsimony, dan comparative (Brown, 2006). Absolut fit diintrepetasikan sebagai proporsi dari sampel data yang mampu dijelaskan oleh sebuah model (Kline, 2011). Indeks absolut fit ini bekerja sebagaimana $R^{2}$. Misalnya, jika indes ini menunjukkan angka .85 , maka dapat dikatakan bahwa model dapat menjelaskan $85 \%$ kovarian data sampel. Parsimony fit berkaitan dengan keputusan menjaga keseimbangan antara menambah parameter guna meningkatkan indeks fit atau menguranginya untuk mendapatkan validitas yang baik (Foster et al., 2006). Indeks parsimony fit ini berfungsi sebagai formula koreksi (correction formula) untuk kompleksitas model (Kline, 2011). Sebuah model dengan indeks parsimony fit berarti sebuah model fit dan memiliki tingkat kompleksitas yang lebih minim. Terakhir, indeks incremental/comparative fit. Indeks ini mengidentifikasi peningkatan kecocokan (fit) relatif dibandingkan dengan model independen (baseline model). Model independen ini biasanya disebut null hypothesis model yang memiliki tingkat fit buruk.

Tabel 7: Hasil Analisis Jalur dengan model yang dihipotesiskan

\begin{tabular}{|c|c|c|c|c|c|}
\hline \multirow{2}{*}{ Hipotesis } & \multicolumn{2}{|c|}{ Variabel Penelitian } & \multirow{2}{*}{ Loading } & \multirow{2}{*}{ Sig } & \multirow{2}{*}{ Ket } \\
\hline & Dependen & Independen & & & \\
\hline $\mathrm{H} 1$ & Komitmen Identifikasi & Partisipasi & 0.14 & $2.02 * *$ & Didukung \\
\hline $\mathrm{H} 2$ & & Pelayanan Publik & 0.40 & $4.89 *$ & Didukung \\
\hline $\mathrm{H} 3$ & & Cakupan Pekerjaan & 0.04 & 0.52 & Tidak didukung \\
\hline $\mathrm{H} 4$ & & Politik & -0.05 & -1.06 & Tidak didukung \\
\hline H5 & & Kualitas Supervisi & 0.23 & $3.83 *$ & Didukung \\
\hline H6 & & Peningkatan Karier & 0.17 & $3.52 *$ & Didukung \\
\hline $\mathrm{H} 7$ & Komitmen Afiliasi & Partisipasi & 0.26 & $3.26 *$ & Didukung \\
\hline $\mathrm{H} 8$ & & Politik & -0.14 & $2.47 * *$ & Didukung \\
\hline H9 & & Kualitas Supervisi & 0.35 & $4.24 *$ & Didukung \\
\hline $\mathrm{H} 10$ & & Peningkatan Karier & 0.13 & $1.95 * * *$ & Didukung \\
\hline H11 & Komitmen Pertukaran & Partisipasi & 0.15 & $1.77 * * *$ & Didukung \\
\hline H12 & & Politik & -0.13 & $2.11 * *$ & Didukung \\
\hline $\mathrm{H} 13$ & & Kualitas Supervisi & 0.12 & 1.41 & Tidak didukung \\
\hline H14 & & Peningkatan Karier & 0.23 & $2.72 *$ & Didukung \\
\hline H15 & & Pembelajaran & 0.08 & 1.30 & Tidak didukung \\
\hline $\mathrm{H} 16$ & & Kepuasan Gaji & 0.27 & $2.95 *$ & Didukung \\
\hline H17 & Keinginan Bertahan & Komitmen Afiliasi & 0.05 & 0.86 & Tidak didukung \\
\hline $\mathrm{H} 18$ & & Komitmen Identifikasi & 0.05 & $7.07 *$ & Didukung \\
\hline H19 & & Komitmen Pertukaran & 0.19 & $2.72 *$ & Didukung \\
\hline $\mathrm{H} 20$ & & Tingkat Pendidikan & -0.03 & -0.52 & Tidak didukung \\
\hline $\mathrm{H} 21$ & & Alternatif Pekerjaan & -0.23 & $-4.37 *$ & Didukung \\
\hline $\mathrm{H} 22$ & Intensi Turnover & Keinginan Bertahan & -0.58 & $-8.39 *$ & Didukung \\
\hline $\mathrm{H} 23$ & & Tenure & 0.08 & 1.30 & Tidak didukung \\
\hline $\mathrm{H} 24$ & Perilaku Ekstra-Peran & Komitmen Afiliasi & 0.32 & $5.19 *$ & Didukung \\
\hline $\mathrm{H} 25$ & & Motivasi internal & 0.28 & $4.53 *$ & Didukung \\
\hline $\mathrm{H} 26$ & & Posisi/Jabatan & 0.09 & $2.19 * *$ & Didukung \\
\hline $\mathrm{H} 27$ & & Pelayanan Publik & 0.35 & $5.11 *$ & Didukung \\
\hline
\end{tabular}

Ket: *signifikan pada $\alpha \leq 0.01$

$* *$ signifikan pada $\alpha \leq 0.05$

$* * *$ signifikan pada $\alpha \leq 0.10$ 
Tabel 8: Hasil pengukuran Overall Goodnes of Fit

\begin{tabular}{llccl}
\hline No & Indikator Goodnes of Fit & $\begin{array}{c}\text { Cut-off yang } \\
\text { direkomendasikan }\end{array}$ & Hasil Estimasi & Penilaian \\
\hline & Absolut fit & $\geq 0,05$ & 0,001 & Kurang Baik \\
$\mathbf{1}$ & Prob. Chi-Square & $\geq 0,90$ & 0.88 & Kurang Baik \\
$\mathbf{2}$ & GFI & $\leq 0,10$ & 0,077 & Baik \\
$\mathbf{3}$ & SRMR & $\leq 0,10$ & & \\
& Parsimony fit & Model Terkecil & 0,098 & Baik \\
$\mathbf{4}$ & RMSEA & Model Terkecil & 519,69 & Baik \\
$\mathbf{5}$ & ECVI & $\geq 0,90$ & Baik \\
$\mathbf{6}$ & AIC & $\geq 0,90$ & 0,98 & Baik \\
& Comparative fit & 0,98 & Baik \\
$\mathbf{7}$ & CFI & & & \\
$\mathbf{8}$ & NFI & &
\end{tabular}

Sumber: hasil olah data

Tabel 8 di atas menunjukkan hasil pengukuran overall goodness of fit dari model penelitian ini. Meskipun tidak semua indikator pengukuran goodness of fit pada model ini menunjukkan hasil yang baik, setidaknya dalam setiap jenis indeks ada indikator indeks yang memenuhi standar baiknya sebuah model. Pada indeks absolut fit, hanya satu indeks yang dapat dikategorikan baik, sedangkan sisanya bisa dikatakan kurang baik. Sedangkan pada indeks comparative fit dan parsimony fit hasil pengukurang menunjukkan hasil yang baik. Dengan demikian dapat disimpulkan bahwa model pada penelitian ini baik dan dapat dilakukan analisis terhadapnya.

\section{PEMBAHASAN}

Penelitian ini memberikan hasil menarik dalam pengembangan teori komitmen organisasional. Sebagai contoh, Balfour and Wechsler (1996) menemukan bahwa komitmen organisasional memiliki pengaruh pada keinginan seseorang untuk bertahan di organisasi. Namun secara spesifik, komitmen afiliasi justru tidak secara signifikan mempengaruhi seseorang hendak bertahan di organisasinya melainkan hanya berpengaruh pada kemauannya untuk bekerja melebihi deskripsi pekerjaan yang terkandung.

Variabel partisipasi dan pengembangan karier sebagai variabel organisasional berpengaruh langsung terhadap ketiga jenis komitmen organisasional. Hal ini membuktikan bahwa kesempatan untuk berpartisipasi dalam proses pembuatan keputusan di pekerjaan dan kesempatan pengembangan karier yang jelas secara umum mampu meningkatkan komitmen organisasional karyawan. Variabel lain seperti penetrasi politik hanya berpengaruh pada komitmen afiliasi dan komitmen pertukaran, namun tidak pada komitmen identifikasi. Sebaliknya, variabel kualitas supervisi hanya berpengaruh pada komitmen identifikasi dan komitmen afiliasi, namun tidak pada komitmen pertukaran.

Meskipun beberapa variabel di atas memiliki pengaruh bersamaan pada dua atau tiga jenis komitmen organisasional, bukan berarti variabel tersebutlah yang memiliki pengaruh terbesar pada variabel dependennya. Sebagi contoh, variabel pelayanan publik mempunyai pengaruh paling kuat pada komitmen identifikasi. Kemudian, secara berturutturut variabel kualitas supervisi, pengembangan karier dan partisipasi mempengaruhi komitmen identifikasi. Sebaliknya, dua variabel lain yaitu variabel cakupan pekerjaan dan penetrasi politik tidak memiliki pengaruh terhadap komitmen identifikasi. Hasil tersebut mengindikasikan bahwa komitmen seorang pegawai negeri sipil yang bersandar pada kemauannya mengidentifikasikan diri dengan tujuan dan sasaran organisasi akan meningkat seiring dengan besarnya kesempatan untuk melayani publik di bidang pekerjaannya. Selain itu, perubahan besaran komitmen ini juga dipengaruhi oleh kualitas supervisi, kejelasan pengembangan karier, dan kesempatan berpartisispasi dalam proses pembuatan keputusan yang terkait dengan pekerjaannya.

Selanjutnya, komitmen afiliasi dipengaruhi oleh semua variabel yang telah dihipotesiskan, yaitu partisipasi, penetrasi politik, kualitas supervisi, dan pengembangan karier. Variabel kualitas supervisi memberrikan pengaruh paling kuat pada komitmen afiliasi 
ini. Ketika supervisor peduli terhadap pola keseharian karyawan dan memberi kepercayaan dalam melakukan pekerjaan, maka akan memperkuat komitmen seseorang pada organisasi. Artinya, kegiatan supervisi menciptakan lingkungan sosial yang mendukung pekerjaan dan bersifat produktif dalam organisasi (Balfour and Wechsler, 1996).

Dalam konteks komitmen afiliasi ini, variabel penetrasi politik memiliki perlakuan yang berbeda dengan ketiga variabel yang lain. Jika peningkatan variabel partisipasi, kualitas supervisi dan pengembangan karier diiringi peningkatan komitmen afiliasi yang dimiliki oleh karyawan, justru hal tersebut berlaku sebaliknya pada variabel penetrasi politik. Sehingga, semakin besar penetrasi politik pada praktik-praktik managerial atau dalam proses pembuatan keputusan di dalam organisasi akan menurunkan komitmen afiliasi karyawan.

Di sisi lain, variabel terkuat yang menjadi anteseden komitmen pertukaran berbeda dengan kedua jenis komitmen yang lain. Dua variabel yang cukup kuat mempengaruhi komitmen pertukaran adalah kepuasan gaji dan pengembangan karier kemudian disusul dengan variabel partisipasi dan penetrasi politik. Akan tetapi, variabel kualitas supervisi dan pembelajaran tidak terbukti berpengaruh pada komitmen pertukaran.

Fakta-fakta di atas menunjukkan bahwa kepuasan gaji seorang karyawan merefleksikan kualitas hubungan resiprokal yang terjadi antara organisasi dan karyawan. Jika seorang karyawan puas dengan gaji yang dimiliki tentu ia akan semakin berkomitmen pada organisasi. Demikin halnya dengan pengembangan karier. Kejelasan pengembangan dan jalur karier akan mempermudah karyawan untuk melakukan perencanaan mengenai peningkatan kapasitas diri sehingga ia pantas menduduki posisi yang lebih tinggi.

Pada penelitian ini, keinginan untuk bertahan di organsiasi sebagai salah satu dampak komitmen organisasional hanya dipengaruhi oleh komitmen identifikasi, komitmen pertukaran dan adanya alternatif pekerjaan lainnya. Justru komitmen afiliasi tidak memiliki pengaruh yang signifikan. Pengaruh signifikan komitmen afiliasi hanya berada pada variabel perilaku ekstra-peran. Hasil ini mengindikasikan dua hal menarik yang sangat berbeda. Pertama, fungsi relasi sosial dalam pekerjaan tidak mengikat secara psikologis bagi seseorang untuk tetap bertahan dalam sebuah organisasi. Kedua, relasi sosial berpengaruh kuat pada perilaku seseorang untuk berbuat melebihi peran yang diwajibkan. Dengan demikian, secara terpisah kita dapat mengambil kesimpulan bahwa kelompok kerja yang kohesif secara sosial mempengaruhi keinginan seseorang untuk berperilaku melebihi peran yang seharusnya ia miliki, akan tetapi hal tersebut tidak berpengaruh pada keinginan mereka untuk tetap berada di organisasi.

Selanjutnya, variabel perilaku ekstraperan pun tidak hanya dipengaruhi oleh komitmen afiliasi, melainkan dipengaruhi juga oleh motivasi internal seseorang, posisi atau jabatan yang sedang diampu dan kesempatan yang tersedia untuk pekerjaan yang langsung melayani publik. Semakin besar komitmen afiliasi dan motivasi internal seseorang, semakin tinggi jabatannya, serta semakin banyak kesempatan melayani publik secara langsung akan meningkatkan kemungkinan seseorang berperilaku melebihi peran yang diwajibkan kepadanya. Terakhir, intensi turnover yang dimiliki oleh seorang karyawan terbukti berbanding terbalik dengan keinginannya untuk bertahan di organisasi. Tetapi, hipotesa bahwa intensi turnover akan berkurang seiring dengan pertambahan lama bekerja (tenure) seorang karyawan di organisasi tidak terbukti. Artinya, seberapa lama pun seseorang bekerja di organisasi tidak akan mempengaruhi intesitas keinginan karyawan untuk melakukan turnover.

\section{PENUTUP}

Hasil pengujian tentang peranan variabelvariabel kelompok anteseden berpengaruh pada komitmen organisasional sektor publik (afiliasi, identifikasi, dan pertukaran) dan dampak komitemen organisasional pada variabelvariabel kelompok keluaran (outcome) mengungkapkan beberapa temuan penting. Pertama, hanya kesempatan berpartisipasi dan kejelasan pengembangan karier secara bersama-sama berpengaruh positif kepada semua komitmen organisasional. Variabel-variabel lainnya mempunyai pengaruh berbeda-beda kepada setiap komitmen organisasional. Kedua, ternyata ketiga komitmen organisasional mempunyai 
keluaran (dampak) yang berbeda-beda. Komitment identifikasi dan pertukaran berpengaruh pada keinginan karyawan bertahan di organisasi, sehingga mengurangi kemauan turnover, Komitmen afiliasi berpengaruh positif pada kemauan berperan lebih (extra-role behavior). Perilaku berrperan lebih ini dipengaruhi oleh motivasi internal yaitu kemauan melayani publik. Ketiga, dugaan kuatnya nilai budaya, seperti nilai kolektivitas di lingkungan organisasi publik dan kemauan melayani publik dapat menjadi penyebab perbedaan hasil penelitian ini dengan penelitian sebelumnya oleh Balfour and Wechsler (1996). Penelitian selanjutnya dapat menguji pengaruh faktor budaya sebagai variabel moderasi untuk hubungan antara variabel-variabel anteseden dan komitmen organisasional. Keempat, implikasi manajerial dari hasil penelitian adalah pentingnya menciptakan iklim relasi sosial dan kesempatan berpartipasi dalam setiap pengambilan keputusan serta kesempatan lebih luas untuk melayani publik untuk menguatkan komitmen organisasional.

\section{DAFTAR PUSTAKA}

Ahmad, S., S. Khurram, S. Rehman, NA. Khan, IU. Shad. 2010. Impact of Organizational Commitment and Organizational Citizenship Behavior on Turnover Intentions of Call Center Personnel in Pakistan. European Journal of Social Sciences. 17 (4). 585-591.

Allen, NJ. and JP. Meyer. 1990. The measurement and antecedents of affective, continuance and normative commitment to the organization. Journal of Occupational Psychology. 63. 1-18

Balfour, DL. and B. Wechsler. 1996. Organizational Commitment: Antecedents and Outcomes in Public Organizations. Public Productivity and Management Review. 19 (3). 256-277

Allen, NJ. and JP. Meyer. 1996. Organizational Commitment: Antecedents and Outcomes in Public Organizations. Public Productivity \& Management Review. 19 (3). 256-27

Angel, H. and JL. Perry. 1981. An empirical assessment of organizational commit- ment and organizational effectiveness. Administrative Science Quarterly. 26. $1-14$

Becker, SH. 1960. Notes on the Concept of Commitment, The American Journal of Sociology. 66 (1).

Brown, TA. 2006. Confirmatory Factor Analysis for Applied Research. London: THE GuILFORD PRESS.

Carnevale, D. and B. Wechsler. 1992. Trust in the public sector: Individual and organizational determinants. Administration \& Society. 23. 471-494.

Carol, SS. and JL. Perry. 1996. Organizational Commitment: Does Sector Matter? Public Productivity \& Management Review. 19 (3). 278-288.

Chusmir, LH. 1988. An Integrative Process Model of Organizational Commitment for Working Women and Men. Journal of Business and Psychology. 3 (1). 88104.

Flynn, DM. and SI. Tannenbaum. 1993. Correlates of Organizational Commitment: Differences in the Public and Private Sector. Journal of Business and Psychology. 8 (1). 103-116.

Foster, J., E. Barkus, and C. Yavorsky. 2006. Understanding adn Using Advanced Statistic. London: THE GuILFORD PRESS

Hackman, JR. and GR. Oldham. 1976. Motivation through the design of work: Test of a theory. Organizational Behavior and Human Performance. 16. 250-279.

Hair, JF., B. Black, B. Babin, RE. Anderson, RL. Tatham. 2006. Multivariate Data Analysis, 5th ed. New Jersey: Prentice Hall International Inc.

Jafri, MH. 2010. Organizational Commitment and Employee's Innovative Behavior. Journal of Management Research. 10 (1). $62-68$

Jaros, SJ., JM. Jermier, JW. Koehler and T. Sincich. 1993. Effects of Continuance, Affective, and Moral Commitment on the Withdrawal Process: An Evaluation 
of Eight Structural Equation Models. The Academy of Management Journal. 36 (5). 951-995.

Kline, RB. 2011. Principles and Practice of Structural Equation Modeling. London: THE GuILFORD PRESS.

Liou, KT. 1995. Professional Orientation and Organizational Commitment among Public Employees: An Empirical Study of Detention Workers. Journal of Public Administration Research and Theory. J-PART. 5 (2). 231-246.

Mayer, RC. and FD. Schoorman. 1998. Differentiating Antecedents of Organizational Commitment: A Test of March and Simon's Model. Journal of Organizational Behavior. 19 (1). 15-28.

Meyer, JP. and L. Herscovitch. 2001. Commitment in The Workplace: Toward a General Model. Human Resource Management Review. 11. 299-326.

O'Reilly, CA. and J.G. Chatman. 1996. Organizational commitment and psychological attachment: The effects of compli- ance, identificatioon, and Internalization on prosocial behavior. Journal of Applied Psychology. 71. 492-499.

Padma, RN. and VS. Nair. 2009. Organizational Culture and Its Impact on Organizational Commitment in Public and Private Organizations. Global Management Review. 4 (1).

Perry, JL. and HG. Rainey. 1988 The PublicPrivate Distinction in Organization Theory: A Critique and Research Strategy. The Academy of Management Review. 13 (2).

Romzek, BS. 1985. The Effects of Public Service Recognition, Job Security and Staff Reductions on Organizational Involvement. Public Administration Review. 45 (2). 282-291.

Sekaran, U. 2006. Research Methods for Business, 4th Ed. John Wiley \& Sons Inc. Edisi bahasa Indonesia.

Steers, RM. 1977. Antecedents and Outcomes of Organizational Commitment, $A d$ ministrative Science Quarterly. 22 (1). 